PAWEE T. DOBROWOLSKI

Collegium Civitas, Warsaw

\title{
BY COACH TO THE SCAFFOLD: THEATRES OF REMORSE IN EIGHTEENTH-CENTURY LONDON
}

\author{
In Memory of Bronisław Geremek
}

On Wednesday 14 January 1767 the London businessman Samuel Orton began his last journey. It lasted several hours and led from the condemned's cell in Newgate Gaol to Tyburn, the usual place of execution for the capital's criminals. He did not travel alone. On the two carts which followed him were carried the twenty-six-year-old Thomas Thornhill, called Captain because of his earlier military service, and two equally young sailors, Walker and Johnston. ${ }^{1}$ Orton led the procession not only because he was older (forty-three years old) and because of his higher social position than the other condemned men. He travelled to his death in a different kind of vehicle, a 'mourning coach', which was suitably emphasized by the press reports. What was the meaning of this difference, given that at the end of the journey all four faced the same punishment: public execution by hanging? Should we read into this traces of 'class' distinctions in English society, which were already clearly visible in the middle of the eighteenth century and which were demonstrated even in such particular circumstances? Such an interpretation would correspond with the well known theses of the historians linked to the 'Warwick school', which has interpreted the English penal system through the prism of the dominant paradigm of the 'owners' of the law and plebeians, casting the latter as the victims of its operation. ${ }^{2}$ A close reading of the reports of this execution

${ }^{1}$ London Magazine, 36, 1767, p. 41. It's competitor, the Gentleman's Magazine, 39, 1767, pp. 20, 44 published a much shorter report.

2 The classic exposition of the thesis of the ideological function of eighteenth-century English penal law is Douglas Hay, 'Property, Authority and the Criminal Law', in Albion's Fatal Tree: Crime and Society in Eighteenth-Century England, ed. Douglas 
reveals distinctions, which seem to show, if not a 'class' difference, then at least a generally discerned distinction in the manner of the criminals' treatment. All four condemned men were hanged for 'the usual time', but their bodies were treated differently. Those of Orton and Thornhill were taken 'in hearses', Johnston's corpse was put into a coffin, while the body of the other seaman was taken by sailors, who attended the execution. These distinctions and their legal, customary and cultural implications will form the subject of the remarks below.

Research on early modern 'theatres of death', public executions, their regulation in law and their cultural and social functions has a long tradition and significant achievements. Public executions have become a separate subject for analysis on the margins of the history of crime, crossing into research on the evolution of penal law, socially established custom, plebeian mores, and the history of psychology and the emotions. Historians are no longer interested only in the processes by which various categories of penal law were created, their practical application and the statistics of early modern criminality. On the one hand we seek - like Pieter Spierenburg - explanations of the social roots of individual examples (in the case of the study cited here - love as the motive for the crime), which illuminate various cultures of human relationships. We seek to show the 'deep context' of collective obsessions which led - as described for colonial New York by Mark Fearnow - to 'the hysteria of killing', the hanging of all those who appeared to threaten the stability of the 'smalltown' community (New York had up to 10,000 inhabitants in the first half of the eighteenth century), or else - as Florike Egmond has shown for the Netherlands - to reconstruct the means of coexistence and activity of the second, criminal and well organized alternative society. ${ }^{3}$ The English case is often used to good effect, partly because of the rich and well-ordered sources, but also because of the conviction, repeated by many historians, that the rules of the penal system were applied with exceptional severity. ${ }^{4}$ It is worth recalling that the father of modern research on the history of En-

Hay et al., London, 1975, pp.17-63. In the same tradition is the 'panoramic' analysis of the 'plebeian victims' of the penal system by Peter Linebaugh, The London Hanged: Crime and Civil Society in the Eighteenth Century, London, 1991.

${ }^{3}$ Peter Spierenburg, Written in Blood: Fatal Attraction in Enlightenment Amsterdam, Columbus, OH, 2004; Florike Egmond, Underworlds. Organized Crime in the Netherlands, 1650-1800, Cambridge, MA, 1993; Mark Fearnow, 'Theatre for an Angry God. Public Burnings and Hangings in Colonial New York, 1741', The Drama Review, 40, 1996, 2, pp. 15-36.

${ }^{4}$ The registers of thousands of criminal trials at the Old Bailey are available online as part of a project led by Professor Tim Hitchcock of the University of Hertfordshire: 〈http://www.oldbaileyonline.org〉. 
glish penal law was a Pole, (Sir) Leon Radzinowicz, who arrived in Great Britain in 1938 with a recommendation from the Ministry of Justice of the Republic of Poland, and who during his career laid the foundations for the achievements of the Anglo-Saxon historiography on the subject. ${ }^{5}$ Radzinowicz's first studies concentrated on the English Bloody Code, a collection of statutes with Elizabethan roots, which categorized even minor infractions (and there were almost two hundred categories), especially against property, as capital offences. The eighteenth century has been considered the apogee of penalization understood and applied in this way.

The result of Radzinowicz's research was the debate begun in the 1970s by Douglas Hay and John Langbein about the social conditions of the functioning of the law. It yielded - thanks to the insights of Michel Foucault and the research of Peter Linebaugh, John Beattie, Simon Devereaux and others - detailed findings, which confirm that as early as the start of the eighteenth century, and certainly from its middle decades, a discussion took place in England regarding the 'strategy of punishment'. The search for a balance between capital punishment and transportation and other milder instruments brought about the gradual questioning of the didactic effectiveness of hanging. Among the contributing factors were the knowledge of Cesare Beccaria's treatise Dei delitti e delle penne (1764) which was swiftly translated into English (1767), the observations made by English jurists led by Sir William Blackstone and the general questioning of the 'efficiency' of the means of detecting crimes and the effectiveness of passing death sentences for common offences. ${ }^{6}$ As early as 1725 the Dutch doctor Bernard Mandeville, naturalized in England, published his treatise An Inquiry into the Causes of the Frequent Executions at Tyburn, in which he strongly criticized the 'theatre' of hanging

${ }^{5}$ Leon Radzinowicz, A History of English Criminal Law and its Administration from 1750, 5 vols, London, 1948-1986, vol. 1: The Movement for Reform 1750-1833. The evolution of Anglo-Saxon historiography in the last century is reviewed by Bruce P. Smith, 'English Criminal Justice Administration, 1650-1850: A Historiographic Essay', Law and History Review, 25, 2007, 3, pp. 593-634.

${ }^{6}$ The debate was first framed by Douglas Hay, 'Property, Authority and the Criminal Law' (n. 2), and John H. Langbein, 'Albion's Fatal Flaws', P\&P, 98, 1983, pp. 96-120. This phase of research is reviewed by Joanna Innes and John Styles, 'The Crime Wave: Recent Writing on Crime and Criminal Justice in Eighteenth-Century England', Journal of British Studies, 25, 1986, 4, pp. 380-435. See John M. Beattie, Crime and the Courts in England, 1660-1800, Princeton, NJ, 1986; idem, Policing and Punishment in London, 16601750: Urban Crime and the Limits of Terror, Oxford, 2001; Simon Devereaux, 'The Making of the Penitentiary Act, 1775-1779', HJ, 42, 1999, 2, pp. 405-33; Anthony J. Draper, 'Cesare Beccaria's Influence on English Discussion of Punishment, 1764-1789', History of European Ideas, 26, 2000, 3-4, pp. 177-99. I have used the English edition of Michel Foucault, Discipline and Punish, London, 1977. 
and argued that public executions encouraged excesses, instead of deterring other criminals. A more penetrative analysis of the 'strategy of punishment' was carried out by Henry Fielding, writer and magistrate, whose work An Enquiry into the Causes of the Late Increase of Robbers, written in 1751 in response to a wave of violence, armed robberies and burglaries that had afflicted London, proposed to confine condemned men in gaols and to 'privatize' the carrying out of the death penalty. Fielding drew particular attention to the inadequate system of detecting crimes, the relegation of victims to the role of silent witnesses and the general powerlessness of the judicial system in the great metropolis, whose streets teemed not only with people who readily escalated verbal abuse into physical violence, but also with far more threatening malefactors and criminals. ${ }^{7}$ Statistics from magistrates' courts that dealt with the most common offences - between neighbours - show that in the period $1730-60$ as many as 53 per cent of cases concerned the threat of violence. ${ }^{8}$ Although minor - as opposed to capital - offences also show a pattern of growth, the death sentence - by hanging - remained the basic means of deterrence throughout the eighteenth century and for obvious reasons attracted the attention of lawyers, commentators and the authors of narrative sources. It can be ar-

${ }^{7}$ The significance of the 'half-private' custody for suspects run by the brothers Fielding on Bow Street for the evolution of court procedures has been analysed by John M. Beattie, 'Sir John Fielding and Public Justice: The Bow Street Magistrates' Court, 1754-1780', Law and History Review, 25, 2007, 1, pp. 61-100.

${ }^{8}$ The following press report can be considered typical: 'Among the many desperate and cruel robberies that were committed about this time three persons returning to Town from Islington about 7 in the evening on Sunday, Feb. 26 [1749 - P.T.D.] were attack'd in Frog-Fields near that place by 3 fellows, who came from behind the barn, and Mr. John Scot foreman to a taylor in Old-Broad street, making some resistance, one of the rogues cut him down the back part of the head with a hanger. They then made their escapes, leaving his two companions whom they had robb'd to take care of him. He was carried to the Red-Lion at Islington, where he languished for 2 or 3 days, and then expired', London Magazine, 18, 1749, p.141. On the basis of jokes and anecdotes Simon Dickie ('Hilarity and Pitilessness in the Mid-Eighteenth Century: English Jestbook Humor', Eighteenth-Century Studies, 37, 2003, 1, pp. 1-22) sketched the cultural field of plebeian verbal aggression. Cf. Robert B. Shoemaker, 'The Decline of Public Insult in London 1660-1800', P\&P, 169, 2000, p. 117; Philip Smith, 'Executing Executions: Aesthetics, Identity, and the Problematic Narratives of Capital Punishment Ritual', Theory and Society, 25, 1996, 2, pp. 248 ff.; Simon Devereaux, 'Recasting the Theatre of Execution: The Abolition of the Tyburn Ritual', P\&P, 202, 2009, pp. 146 f.; Thomas W. Laqueur, 'Crowds, Carnival and the State in English Executions, 1604-1868', in The First Modern Society: Essays in English History in Honour of Lawrence Stone, ed. A.L. Beier, David Cannadine and James M. Rosenheim, Cambridge, 1989, pp. 305-55. The Parisian space of urban criminality has been discussed by Arlette Farge and André Zysberg, 'Les Théâtres de la violence à Paris au XVIII' siècle’, Annales. Histoire, Sciences Sociales, 34, 1979, 5, pp. 984-1015. 
gued, that they had good reason to do so: successive 'crimewaves' meant that the spectacle of public hanging was well known to Londoners. In the years 1770-75 an average of 37 people were hanged annually. According to Simon Devereaux, after 1780 the number of executions rose first by 30 per cent, and then by 70 per cent. ${ }^{9}$ We should not, however, accept the stereotype of an omnipresent and universally applied death penalty. The analysis of sentencing shows that courts used the death penalty after due consideration. Even in cases of statutory capital offences (murder, armed robbery and burglary) the death sentence was sometimes commuted to a lesser punishment. According to contemporary data, collected by the Lord Mayor of London, Theodore Janssen, in 1749-71 1,121 criminals held in Newgate were condemned to death: 443 of them avoided execution (401 of them were sentenced instead to transportation). A substantial number of those criminals whose deeds had led them on a 'statutory' basis to the scaffold had their lives spared. For example, of 81 convicted murderers 72 were hanged. Among 362 condemned highwaymen, the death sentence was carried out in 251 cases, while of 208 burglars 118 were hanged, and 27 pickpockets out of a total of 80 were hanged. As Langbein has established using a sample of 203 cases in the Old Bailey, as many as 83 were acquitted by juries. The London criminal court held eight sessions a year, during which it 'cleansed the gaol': it thus sentenced all those suspects held in Newgate, who had been arrested in London and the neighbouring county of Middlesex. The procedure was swift, with individual cases rarely detaining the judges for more than an hour. After the passing of the Murder Act in 1752, executions were carried out no later than two days after the sentence had been passed. The proceedings and sentence were published in the sessions papers, and so became available for all those interested, especially for the editors of newspapers. They were also the documentary basis for petitions for clemency. ${ }^{10}$

Until 1783, executions were carried out at Tyburn crossroads (now in the vicinity of Marble Arch), which lay beyond the bounds of the city in the parish of St Mary 'by the bourne' (that is, the Tyburn stream, which now

${ }^{9}$ Simon Devereaux, 'Imposing the Royal Pardon: Execution, Transportation, and Convict Resistance in London, 1789', Law and History Review, 25, 2007, 1, p. 120.

${ }^{10}$ Idem, 'The City and the Sessions Paper: "Public Justice" in London, 1770-1800', Journal of British Studies, 35, 1996, 4, pp. 466-503; idem, 'Imposing the Royal Pardon', pp.101-38; Langbein, Albion's Fatal Flaws' (n. 6), pp. 106, 110. The general rise in common offences has been analysed by Peter King, 'Punishing Assault: The Transformation of Attitudes in the English Courts', Journal of Interdisciplinary History, 27, 1996, 1, pp. 43-74. 
runs beneath Marylebone), where in 1571 a gallows was erected, called the 'three-legged stool', on which a dozen or more convicts could be hanged at once. In 1759 the original 'hanging tree' was replaced by a new instrument: a movable gallows. In the eighteenth century the city absorbed the locality and the gallows - along with stands for spectators which were now in a built-up area, close to Oxford Street, the site of residences and workshops. After two centuries of regularly conducted executions the best known London 'theatre of death', to use the term borrowed from Andrea McKenzie with regard to the eighteenth-century spectacle of hanging, possessed a well established place in the urban space and imagination. James A. Sharpe, whose analysis of the seventeenth-century location of public executions in London is still a work of fundamental importance, drew attention to the popularity of chapbooks, in which models of 'good deaths' were described, and emphasized the didactic dimension of the punishment. Sharpe underlined the religious and 'state' conformism which attended the convicts in the last moments of their lives; they were expected to make a public act of remorse and to appeal to the spectators not to follow their sinful path. ${ }^{11}$ He also suggested that at the beginning of the eighteenth century, the hallowed tradition of the presence of clergymen during executions no longer produced the expected speech from the convict which would appropriately move the spectators. Sharpe associated this with the decline of the eschatological dimension of death and its replacement with the secular priority of completing a court procedure. Moreover, Sharpe highlighted the persistence of the early modern debate over the 'deterrent' and 'educational' values of the death penalty. He noted evidence of its becoming ordinary - as in the popular saying noted in 1725 , that 'there is nothing in being hang'd, but a wry neck, and a wet pair of breeches' - but he also

${ }^{11}$ J. A. Sharpe, “Last Dying Speeches”: Religion, Ideology and Public Execution in Seventeenth-Century England', P\&P, 107, 1985, pp. 144-167; Steven Wilf, 'Imagining Justice: Aesthetics and Public Executions in Late Eighteenth-Century England', Yale Journal of Law and the Humanities, 5, 1993, pp. 51-78; Andrea McKenzie, 'Martyrs of Low Life? Dying "Game" in Augustan England', Journal of British Studies, 42, 2003, 2, pp. $167-$ 205; eadem, Tyburn's Martyrs: Execution in England, 1675-1775, London, 2007; Peter Linebaugh, 'The Ordinary of Newgate and His Account', in Crime in England, 1550-1800, ed. J.S. Cockburn, Princeton, NJ, 1977, pp. 246-68. Pieter Spierenburg, The Spectacle of Suffering: Executions and the Evolution of Repression. From a Preindustrial Metropolis to the European Experiences, Cambridge, 1984; Frances E. Dolan, "'Gentlemen, I Have One Thing More to Say": Women on Scaffolds in England, 1563-1680', Modern Philology, 92, 1994, 2, pp. 157-78; Louis Masur, Rites of Execution, Oxford, 1989; Devereaux, 'Recasting the Theatre of Execution' (n. 8), pp. 127-74. 
stated that the tradition of 'speeches from the scaffold' kept its own dynamics and remained lively. ${ }^{12}$

Below I shall use several press reports of executions at Tyburn which were placed in London monthlies - in media which in the eighteenth century, following the daily newspapers, replaced the earlier chapbooks and in a hitherto unknown way (qualitatively and quantitatively) accumulated, related and ordered information about many aspects of daily life in the city. They devoted much space to criminals, their trials and their executions. Newspapers used their own reporters' accounts as well as the easily available session papers published at the conclusion of each of the eight monthly sessions of the London criminal court (in the second half of the eighteenth century 320 copies of each session's paper were published at the city's expense), providing a wealth of detail for each of the cases heard..$^{13}$ I shall try to draw attention to distinctions and differences appearing in the models of the 'theatricization of public dying', which testify that in the city space of eighteenth-century London the spectacle of death gradually saw changes that took place in the social fabric of the city - more quickly than at Tyburn.

The custom of 'speeches from the scaffold' continued in the eighteenth century, although the London press, generally because of the surfeit of information and the limited space in its columns, did not usually report them at length. They were however available as an element of the reports of court proceedings, whose didactic role was recognized in 1734 by the writer Samuel Richardson: 'Let the Session-Paper and the Dying-Speaches of unhappy Criminals [...] inform the inconsiderate Youth [...] how naturally, as it were Step by Step, Swearing, Cursing, Profaneness, Drunkenness, Whor[e]dom, Theft, Robbery, Murder and the Gallows, succeed one another'. ${ }^{14}$ The public show of remorse remained

12 Sharpe, “"Last Dying Speeches”, pp. 165-67. The ethical and didactic message of eighteenth-century 'court sermons', which were usually preached at the beginning of assizes have been analysed by Randall McGowen, "He Beareth Not the Sword in Vain": Religion and the Criminal Law in Eighteenth-Century England', Eighteenth-Century Studies, 21, 1987-1988, 2, pp. 192-211, emphasizing the pressure from clergymen for the carrying out of severe sentences.

${ }^{13}$ On the role of the press in raising criminal themes see Jeremy Black, The English Press in the Eighteenth Century, London, pp. 99-108; James Oldham, 'Law Reporting in the London Newspapers, 1756-1786', American Journal of Legal History, 31, 1987, 3, pp. 177-206; John Styles, 'Sir John Fielding and the Problem of Criminal Investigation in Eighteenth-Century England', Transactions of the Royal Historical Society, 5th Series, 33, 1983, pp. 135 ff.; Beattie, 'Sir John Fielding' (n. 7), pp. 69 f., 85 f.

${ }^{14}$ Quoted after Devereaux, 'The City' (n. 10), p. 496. Cf. Ian Bell, Literature and Crime in Augustan England, London, 1994, pp. 72-74. 
a constant element of the landscape of the scaffold at London's edge, although both the press 'carrier', through which didactic messages were spread, and the way in which those messages were reported to London readers, changed as a result of an inundation of various, not only criminal news. In the eighteenth century the newspapers were a basic source of information about the punishments administered, with other media functioning alongside: in an engraving by William Hogarth from 1747, titled The Idle 'Prentice Executed at Tyburn, the artist depicted a cart with a coffin and a clergyman, while at the foot of the scaffold was a seated woman, who while holding a child in one hand, was selling with the other the previously printed 'last speech' of the condemned man. ${ }^{15}$

From the description of the execution, which took place on 25 February 1754 in Ilchester, the reader learned that 'the noted John Poulter, alias Baxter, who had made his escape out of gaol and was soon retaken,was executed at Ilvechester, behaving very penitently, and with decent resolution. As soon as he arrived at the gallows he stood up in the cart three times, declaring aloud, that the report of the gaoler's having contrived to let him escape was without any foundation. He then addressed himself to the people, desiring them to take warning by his unhappy end, and avoid bad company; acknowledging that he deserved to suffer death, but that most of his accomplices did more so.' Summaries of the descriptions of executions - and court procedures - carried out by newspapers replicated the basic structure of the official reports and conveyed a shortened version of the last words pronounced by the condemned men. In the case of Poulter we may obviously wonder which fragments of the speech were 'edited' or even previously agreed with him. From the press report it can be concluded that it served several ends simultaneously: it pronounced a standard formula of remorse, it absolved the gaoler (threatened with the noose) from guilt and pointed to the still greater guilt of his accomplices, who remained a source of danger to those assembled. ${ }^{16}$

Some press reports can be found, which appear to be only pale and distorted reflections of the earlier (one would like to say 'baroque') mo-

${ }^{15}$ The appetite for 'scaffold literature' continued to be hearty: in 1768 a four-volume book was published under the significant title The Tyburn Chronicle; or Villainy Display'd in All Its Branches, which 'to support virtue and religion' related the life-stories of those hanged; see Devereaux, 'The City', p. 497. This type of literature, created, among others, by a prison chaplain, disappears about 1770. Cf. McKenzie, 'Martyrs', pp. 170 ff. On Hogarth's engraving see Barbara Jaffe, 'William Hogarth and Eighteenth Century English Law Relating to Capital Punishment', Law and Literature, 15, 2003, 2, p. 268 and il. 1; cf. a more cautious assessment by Simon Devereaux, 'Recasting the Theatre of Execution', p. 142.

${ }^{16}$ London Magazine, 23, 1754, p. 138. 
tif of the 'glorious conversion' of the sinner in the face of death. The cobbler John Williamson, a 'a tall man about forty-six years of age', sentenced for starving his wife to death, was taken to Chiswell Street in Moorfields. A different place from the usual Tyburn was chosen as his place of execution, because the didactic aim was to hang him in the district where he had lived and was known. Two Anglican clergymen accompanied him, along with a 'a Methodist teacher', who prayed for him 'for a full hour'. Then, 'it was with much difficulty that the clergymen could prevail upon him to acknowledge his crime, but at last, just before the cart drew off one of the clergymen informed the people that he had confessed to murder; and further that his disorderly life had been a principal means of bringing him into that unfortunate situation, and hoped the people would pray for his soul.' The newspaper reported - regrettably without explaining the reason - that the execution was witnessed by 10,000 people, 'a great number of whom were women'. ${ }^{17}$

English court documents and their public circulation generated by printed pamphlets summarizing individual cases and press reports of the outcome of sessions at the Old Bailey - the main London institution dealing with sentences for criminal offences - are a unique resource, containing thousands of reports about who was sentenced and for what crimes. Historians studying the English (or British) judicial system and its social and cultural ramifications have made extensive use of this collection, including attempts at statistical analysis, despite the known methodological limitations of such material.

The reading of hundreds of individual, short press reports about crimes committed reveals an extraordinary panorama of urban criminality in the largest metropolis of eighteenth-century Europe. In January 1751 the death sentence was passed on, among others, a professional stage-boxer, James Field, who besides plying his own pugilistic trade robbed a passer-by of his spectacles, a tobacco case, and thirteen shillings. William Vincent relieved another of silver trouser-buckles and

${ }^{17}$ London Magazine, 36, 1767, p. 41. Fortunately the rival monthly Gentleman's Magazine used the court proceedings more exactly, and informed its readers that the cobbler had murdered his wife with premeditation, because his wife the poor creature was a kind of idiot, who having a sum on money left for her maintenance Williamson to possess himself of the money found means to marry her'. An account followed of the sufferings of the victim and the note that the assembled crowd, consisting of persons who knew him and his neighbours, wanted to tear him to pieces, so the condemned man himself asked the executioner to carry out the sentence quickly. Gentleman's Magazine, 39, 1767, p. 44. Crimes in the category of 'domestic cruelty' are discussed by Margaret Hunt, 'Wife-Beating, Domesticity and Woman's Independence in Eighteenth-Century London', Gender and History, 4, 1992, pp. 10-35. 
was similarly sentenced to death. Richard Parsons, a repeat-offender previously sentenced to transportation, had returned to England despite the fact that another brush with the law would take him to the gallows. The thirteen persons sentenced by the court to death in that session had mostly committed street robbery, burglary or theft involving tablewares, watches, money, hats and wigs. Without losing sight of death sentences - and executions - it should be emphasized that the evolution of the British judicial system in the eighteenth century shows a consistent tendency towards the reduction of such sentences and their replacement by transportation which was considered as a substitute for more severe penalties - and lesser punishments. In the cited January session of the Old Bailey, besides the thirteen death sentences there were also 35 sentences of transportation to the colonies and two cases of branding with a hot iron. This last category, along with the stocks or pillory, belonged to the typical means of denoting 'punishments of public shame', deeply rooted and traditional forms of infamy, whose social presence and longevity has been brilliantly explored by Natalie Zemon Davis. ${ }^{18}$ Transportation to America - for seven or fourteen years or for life - was regarded as a socially beneficial punishment, and was used as a substitute for the death sentence. In cases where the convict returned from banishment before serving his sentence, he was considered a re-offender and punished with the noose.$^{19}$ Anglo-Saxon historiography has conducted a thorough analysis of the extent and the social and economic significance of sentences of transportation. For most of the eighteenth century they dealt with the banishment to America. Between 1718 and 1775 this was the destination for some 50,000 convicts, mostly petty thieves, vagrants and prostitutes, who became 'white slaves' and supplied the colonial labour market. ${ }^{20}$

18 On 'Friday, January 18 [1745] David Manning and John Davis were sentenced to stand the pillory and to be imprisoned, the former for six, the latter for three months for sodomitical practices', London Magazine, 14, 1745, p. 47. Cf. Randolph Trumbach, 'Sex, Gender, and Sexual Identity in Modern Culture: Male Sodomy and Female Prostitution in Enlightenment London', Journal of the History of Sexuality, 2, 1991, pp. 186-203. On the 'rituals of shame' cf. Natalie Zemon Davis, Society and Culture in Early Modern France, Stanford, CA, 1975, pp. 106-81; William Beik, 'The Violence of the French Crowd from Charivari to Revolution', P\&P, 197, 2007, pp. 75-110.

${ }^{19}$ For example: the Jew Jakub Cardoso, condemned to transportation, broke out of Newgate Gaol, and on being caught was sentenced to death; on Richard Parsons, sentenced to death for returning before serving his time, see the London Magazine, 12, 1743, p. 619; ibid., 20, 1751, p. 43. Cf. 'John Payan otherwise Pidgeon [condemned to death - P.T.D.] for privately stealing a Watch, who seem'd very much concern'd and begg'd the favour of the Court of Transportation for Life, tho' a reputed pickpocket for about 20 years', ibid., 15, 1746, p. 476.

${ }^{20}$ London Magazine, 20,1751, p. 43. On transportations to America see: Kenneth 
Even if every one of those condemned to death had actually died in that way, the procedure and scenography of hanging were differentiated in such a way so that the assembled mob had the basic information about the circumstances and reasons for the execution. On Monday 14 March 1737, an oar and naval signs were carried before two carts taking convicts to their place of execution: emblems testifying that the condemned men belonged to the category called 'pirates', and that the sentences had been passed by the Court of Admiralty, an institution that dealt with crimes committed at sea and on board British ships. The procedures and customs of the Court of Admiralty require further historical investigation, but it is known that the court met in the same building as the municipal court that heard criminal cases. Its sessions were however less frequent. The judges, and subsequently the convicts were marked by the emblem of the institution: the oar (in the case of the judges, a silver oar) and its cases essentially concerned crimes committed 'on the high seas'. It is difficult to recognize the four convicts of March 1737 as pirates, although in the public imagination they may have been brethren to the members of the famous fraternity of the West Indies. As Marcus Rediker has shown, the colourful figures of 'real' - Caribbean - pirates disappeared in the first decades of the eighteenth century under pressure from the well-organized military and judicial machinery of the state..$^{21}$ Their ethos remained, however, notably their 'romantic' vision of a maritime proto-democracy of rebels, sold in cheap pamphlets as a literary construction originating in the picaresque novel. The convicted quartet had worked

Morgan, 'The Organization of the Convict Trade to Maryland: Stevenson, Randolph \& Cheston, 1768-1775’, William \& Mary Quarterly, 3rd Series, 42, 1985, 2, pp. 201-27; A. Roger Ekirch, 'Bound for America: A Profile of British Convicts Transported to the Colonies, 1718-1775', William \& Mary Quarterly, 3rd Series, 42, 1985, 2, pp. 184-200; idem, Bound for America: The Transportation of British Convicts to the Colonies, 1718-1775, Oxford, 1987; Aaron S. Fogelman, 'From Slaves, Convicts, and Servants to Free Passengers: The Transformation of Immigration in the Era of the American Revolution', Journal of American History, 85, 1998, 1, pp. 43-76; Farley Grubb, 'The Transatlantic Market for British Convict Labor', Journal of Economic History, 60, 2000, 1, pp. 94-122; idem, 'The Market Evaluation of Criminality: Evidence from the Auction of British Convict Labor in America, 1767-1775', American Economic Review, 91, 2001, 1, pp. 295-304; Gwenda Morgan and Peter Rushton, Eighteenth-Century Criminal Transportation: The Formation of the Criminal Atlantic, New York, 2004; Devereaux, 'Imposing the Royal Pardon' (n. 9), pp. 101-38.

${ }^{21}$ Marcus Rediker, Between the Devil and the Deep Blue Sea: Merchant Seamen, Pirates, and the Anglo-American Maritime World,1700-1750, Cambridge, 1987; idem, Villains of All Nations: Atlantic Pirates in the Golden Age, Boston, MA, 2004. Cf. the interesting study of piracy in the Indian Ocean: Patricia Risso, 'Cross-Cultural Perceptions of Piracy: Maritime Violence in the Western Indian Ocean and Persian Gulf Region during a Long Eighteenth Century', Journal of World History, 12, 2001, 2, pp. 293-319. 
on the seas, on British merchant ships, but instead of 'piratical' deeds they had committed common crimes - in European waters. We discover that two of them - mate Williams and seaman Johnston - had murdered the master of the brigantine Dove with knives, when the ship was moored in Livorno. Unluckily for them, the captain's servant, a witness to the murder, jumped overboard and brought help from other English ships. Another of the 'pirates', mate Coyle, turned out to be the leader and instigator of a mutiny in August 1735 off the Turkish coast on board the pinnace St John. The victim was the ship's captain who, despite pleas for mercy had his head bludgeoned, and his corpse thrown into the sea. The arm of British maritime law was long, however, and the criminal was finally caught - in Tunis - and brought to London. The press report, which faithfully gave the details of the trial, noted that the condemned men were 'hanged in chains' as a sign of their criminal past and particularly anti-social behaviour. In other cases judged by the Admiralty Court we learn that desertion, all kinds of mutiny and insubordination, shooting a customs official and burglary with the aim of landing goods without paying duties, and an attempt to burn a ship in order to obtain an insurance payout were all considered 'piracy'. 'Pirates' were not hanged together with other criminals close to the city centre at Tyburn. Their carts went in procession towards the Thames and their execution took place on the riverside, at the place known as 'Execution Dock'. ${ }^{22}$

The well-known work of Eric J. Hobsbawm on the social roots of banditry suffices to remind us that in parallel to the image of the pirate godless, pugnacious, but close to 'simple people' - functioned the image of his equivalent on land - the highwayman, who robs travellers and seizes private and public property alike. ${ }^{23}$ The richness of this literary motif, known in its modern version from the foothills of the Tatra mountains (in the early eighteenth century) to the American prairies (in the nineteenth century) hardly needs recalling, although, as Lincoln Faller has stated, the abundance of this kind of criminal biography owes most to the English market for this type of literature. Gillian Spriggs, the author of a monograph on English banditry, underlines its own kind of natural fascination with a persona of an armed robber. The transformations of this motif are also important. Juraj Janosik, a Slovak bandit from the Trenčin district, hanged on 17 March 1718 (for robberies, but not for murder) had a second life a century after his execution as a romantic defender of the

${ }^{22}$ London Magazine, 6, 1737, pp. 163-64; ibid., 12, 1742, p. 619; ibid., 23, 1754, p. 91; Devereaux, 'Recasting the Theatre of Execution', p. 139.

${ }^{23}$ Eric J. Hobsbawm, Bandits, New York, 1969. 
Slovaks from feudal oppression, whereas his English contemporary Dick Turpin, the leader of a band of highwaymen and the hero of novellas, did not hesitate to use firearms - with fatal results. ${ }^{24}$ Still more important, however (returning to the moment when the criminals receive their just penalties) is that the narratives of highwaymen's deaths seem often to be written in a different style to that in which the hanging of other convicts is related. Instead of showing remorse and making elevating speeches, Turpin and many of his imitators, such as 'Gentleman Jack' Sheppard, hanged on 16 November 1724, or the band-leader Jonathan Wild, executed a year later, displayed to the crowd an arrogant and insolent attitude at the hour of their deaths. They mocked the judicial process by exchanging smiles with women on their way to the scaffold and spending the last night of their lives (in gaol) drinking and playing cards, thus publicly ridiculing the apparently obligatory paradigm of remorse. ${ }^{25}$

Every attempt to describe the 'hanging' rhythm of urban culture in the categories of didactic theatre should take into account the intended scenario leading from proven guilt and the sentence to the public show of remorse. However, such efforts should also incorporate individual reactions and those acted out according to another code - resistance or submission - by the most important participants in the drama. 'Yesterday morning', the Universal Magazine informed its readers on 14 February 1765 ,

Matthew James, for forgery, John Ward, for robbery in Moorfields, John Routon, for house-breaking in Chick-lane, and Edward Williams for robbing the house of Right Hon. Earl Verney of plate, etc. were, pursuant to their sentences, executed at Tyburn. Williams, regardless of the numerous spectators, prayed in the most fervent manner from Newgate to the place

${ }^{24}$ The fortunes of Turpin's band are reconstructed by Derek Barlow, Dick Turpin and the Gregory Gang, London and Chichester, 1973. The transformation of the Janosik legend (and the earlier scholarly literature) is discussed by Martin Votruba, 'Hang Him High: The Elevation of Janosik to an Ethnic Icon', Slavic Review, 65, 2006, 1, pp. 24-44. Migrations of legends and explosions of 'bandit literature' are analysed by Lincoln B. Faller, 'Criminal Opportunities in the Eighteenth Century: The "Ready-Made" Contexts of the Popular Literature of Crime', Comparative Literature Studies, 24, 1987, 2, pp. 120-45; idem, Turned to Account: The Forms and Functions of Criminal Biography in Late Seventeenth-and Early Eighteenth-Century England, New York, 1987. See Michael Harris, 'Trials and Criminal Biographies: A Case Study in Distribution', in Sale and Distribution of Books from 1700, ed. Robin Myers and Michael Harris, Oxford, 1982, pp. 1-36; Gillian Spriggs, Outlaws and Highwayman: The Cult of the Robber in England from the Middle Ages to the Nineteenth Century, London, 2001, p. 12 ('national worship').

${ }^{25}$ 〈http://www.stand-and-deliver.org.uk/highwaymen〉 [accessed 17 May 2012]. Cf. McKenzie, 'Martyrs', pp. 183 ff.; P. Smith, 'Executing Executions', pp. 245 ff. 
of execution, Ward dying a Papist, turned his back upon the minister, and Routon near St. Giles's-pound pulled off his shoes and threw them among the crowd. ${ }^{26}$

Williams conformed to the minimum expected of him by 'cultural correctness', Ward showed himself a heretic, considered a foreign enemy by the crowd (he was probably Irish), while Routon - judging by the kind of offence he had committed, a common London criminal - made a demonstrative gesture challenging the assembled spectators: a sign of despair and impotent rage.

Let us return to the last journey of Samuel Orton. Was the use of a closed coach instead of an open cart (only after 1763 were the carts marked in black cloth) a sign of particular distinction for this convict? What had he done to deserve better treatment than hundreds of others, whom the assembled public could watch in a procession of several hours from Newgate to the capital's gallows? The press report records that "when they came to the place of execution they behaved devoutly and penitently. Mr. Orton took leave of some friends with great composure, but Thornhill, before the cart drew away [which meant hanging P.T.D.] put up his cap five times seeming very unwilling to leave this world'. The very fact that Orton was accompanied by friends calls for reflection. Most reports of Tyburn hangings note only the main protagonists, sometimes adding clergymen as well, or (usually nameless) officials and law-enforcers, whose task was to ensure that the solemnity of the execution was not disturbed by the excesses of the crowd. ${ }^{27}$ London's plebeian convicts rarely had their friends described. More usually, mention is made of companions, accomplices or other members of

${ }^{26}$ Universal Magazine, 36, 1765, p. 108.

${ }^{27}$ Surprisingly little is known about London's executioners. They were paid by the City (at the beginning of the eighteenth century with an annual salary of forty pounds). They had additional income from bribes, for example for a swift, so-called painless hanging, from fees from families for taking the body to the cemetery or from doctors, for taking it to the dissecting room. It appears that they were often criminals, and that many continued to come into conflict with the law. The executioner John Price (who carried out the function from 1714), a former sailor, was a chronically indebted drunkard (he was incarcerated in a debtors' prison). While drunk he murdered a street apple-seller and was hanged in 1718. His successor William Marvel was transported in 1719 for the theft of ten silk handkerchiefs, while Thomas Thurlis (executioner in the years 1752-71, which means that he hanged Orton) was arrested in 1763 for the theft of coal from his neighbour's cellar (he told the court that it was because of his poverty). See Gerald D. Robin, 'The Executioner: His Place in English Society’, British Journal of Sociology, 15, 1964, 3, p. 237. 
the band, if the criminal belonged to one. ${ }^{28}$ Orton behaved differently to Thornhill - he was serious and dignified. He was much older than his three fellows in misery. The statistics of convicts transported to America show that crimes were mostly committed by young unemployed or unqualified men (among the transportees almost 40 per cent were less than 24 years old)..$^{29}$

Orton was someone else entirely - a businessman and the father of a family. Taking into account his controlled behaviour it would be natural to expect that, reconciled to his fate, he would make an exemplary speech from the scaffold, thus writing his death into the wider and still lively context of ethically orientated propaganda. He chose, however, a different means of engaging with public opinion: instead of speaking to the crowd gathered below the gallows, several days before his execution, thanks to the assistance of a clergyman who offered him his spiritual support in gaol, he had printed in the London press an open letter, in which he detailed the reasons and circumstances which had led to his imprisonment and expected execution at Tyburn. A pamphlet was published in Hood's printing house, which reported the trial and sentence in detail. The very fact that the accused had reached for his pen and used the possibility of addressing a much wider audience than that which watched public executions shows the different cultural and social sensitivities to which he appealed. Was this proof of the 'birth of silence', the process which Peter Burke suggests took place in Europe from the middle of the seventeenth century and signified the subordination of human behaviour - including that expressed verbally - to

${ }^{28}$ Cf. this report: 'Several constables of St. Andrew's Holbourne attended by a large party of the foot-guards went with a search warrant to a noted publick-house on Saffron Hill in order to detect a large gang of street-robbers, pickpockets, loose women etc. and having surrounded it both before and behind, they secured ten men and two women, and carried them before justice Hole who, after a long examination committed them to Clarkenwell Bridewell. This gang was said to consist of about 50 , tho' no more happened to be in the house, when officers came. One of them attempted to make his escape from the house-top, but a soldier firing at him, he surrendered', London Magazine, 18, 1749, p.141. London was reputed in the eighteenth century to be the worst policed city in Europe, being (unlike Paris) without a professional police force. The 'para-police' organizations, such as citizen-night watches (in 152 parishes of the city), active before the 1829 reform are described by Elaine A. Reynolds, Before the Bobbies: The Night Watch and Police Reform in Metropolitan London, 17201830, Stanford, CA, 1998. Cf. the exemplary study of organized crime by Florike Egmond, 'Crime in Context: Jewish Involvement in Organized Crime in the Dutch Republic', Jewish History, 4, 1989, 1, pp. 75-100. On the use of hoods (so that the spectators would not see the face during the death agony lasting several minutes) see Devereaux, 'Recasting the Theatre of Execution', p. 157.

${ }^{29}$ Ekirch, Bound for America (n. 20), p. 195. 
the newly promoted requirements of correctness and discipline in human relationships ? $^{30}$

Orton's open letter appealed to criteria and categories belonging to a different economic dimension and different set of human relations to those which we can read from notes of the style, place and type of activity of most convicts. Orton belonged to a different world than Joseph Leath, who was hanged for theft commited in a stagecoach, or John Gerrard, a pickpocket who, defying the principle that when it is crowded, it is easy, went to Tyburn because he deftly, but inefficiently extracted an embroidered handkerchief from a spectator's pocket at Drury Lane Theatre, or Thomas Hill, who sold false playing cards. Orton did not belong to the street vagabonds who stole items that easily fell into the hands of thieves and burglars - watches, purses, tableware, bed linen, clothes and which convince contemporary researchers of the inventory of the 'material culture' of eighteenth-century London that an unbroken process of enrichment was taking place among even the lower strata of urban society. ${ }^{31}$ The anonymous clergyman who looked after Orton in gaol left a most flattering image of the condemned man, which was also published in a newspaper. We learn that he was the son of cheesemongers from the parish of St Martin in the Fields, had been well schooled in a provincial town, had been an apprentice to a London bookseller, and thanks to the interest of his friends he obtained the post of clerk on a warship in 1749 . He had shown himself a man of talent, and a conscientious, sincere and honorable official. When he returned to shore - wrote the clergyman, who discerned in Orton's further decisions the origins of the threat to the career of the young man - 'hoping to increase his fortune by dealing in wine and brandy he laid the foundation of his ruin'. ${ }^{32}$ It is immediately obvious that Orton's social context was very different from that inhabited by most of the criminals hanged at Tyburn. Orton belonged to the English 'middle class' which was already clearly visible in the eighteenth century. I use the term while being well aware of the long debate initiated by Edward Patrick Thompson concerning the social categorization of 'pre-industrial' England. ${ }^{33}$ Orton occupied within

${ }^{30}$ A True and Genuine Account of Samuel Orton, who was Executed at Tyburn, on Wednesday January 14, 1767 for a Forgery University Presson the Bank, published by E. Hood, [London] 1767. See Peter Burke, The Art Of Conversation, Cambridge, 1993, p. 140.

${ }^{31}$ London Magazine, 12, 1743, p. 619.

${ }^{32}$ Ibid., 36, 1767, pp. 36-37.

33 See E.P. Thompson, 'Patrician Society, Plebeian Culture', Journal of Social History, 7, 1973-1974, pp. 382-405; idem, 'Eighteenth-Century English Society: Class Struggle without Class?', Social History, 3, 1978, pp.133-65; and his collected studies: idem, Customs in Common, London, 1991. Thompson's historical sociology directly influenced the 
that middle class a place which is easiest to describe using the sociologically appropriate adjective 'lower', but because of his roots in that social stratum and his intellectual and professional attributes, his membership of that eighteenth-century sphere of social advancement and success called 'middle class' is not in doubt.

Orton's open letter, written in gaol a week before his execution, was intended to clear his name - that in itself separated him from other convicts, who had neither the appropriate contacts, nor means, nor probably the idea or need, to undertake such an initiative. The defence of one's good name signifies the different attitude of this condemned man compared to the world of London robbers, and also differentiates him from highwaymen, the 'heroes' of popular narratives, who in the face of death behaved in an extrovert manner and appeared to challenge the judicial process until the very end. Orton's death resembled neither that of an insolent highwayman, nor that of a remorseful criminal who had been determined to tell the assembled mob a moral tale that ended with a show of death-agony on the gallows. For Orton the scaffold was neither the only nor the last point of reference of his life and professional connections. The letter, which is too long and detailed to analyse in each of its fragments, is neither a statement of rebellion against the sentence, nor a plea for forgiveness, and it does not contain a clear message linked to the motif of a remorseful criminal, which was so strongly rooted in the 'penitential' tradition of messages which were sent out from the place of public execution. ${ }^{34}$ Unlike the examples of self-pity expressed in moral terms, it is a statement of business practice in eighteenth-century London. Instead of pleas for forgiveness for a sinful life, it is a barely concealed accusation against the financial mechanisms which caused this wholesaler of alcohol to find himself in a trap of debt and to decide - although his interpretation of the situation was necessarily different from the one reached by the court - to forge a banker's note. Leaving aside other elements of the argument, one factor is noteworthy. Orton writes of sums - hundreds of pounds - which were beyond the reach of the other convicts with whom he shared the gallows. Those sums reflected an economic sphere to which the other criminals had no access. They contented themselves - like James Field, whose loot, besides the spectacles of the victims, was all of thirteen shillings, or the trio of bandits, who shared three pounds which they had taken by force from a passer-by near Covent

analytical methods of penal law proposed by the 'Warwick school'. See the critical review article by Peter King, 'Edward Thompson's Contribution to Eighteenth-Century Studies: The Patrician-Plebeian Model Re-Examined', Social History, 21, 1996, pp. 215-28.

${ }^{34}$ It was published by the London Magazine, 36, 1767, pp. 37-38, and the Gentleman's Magazine, 39, 1767, p. 20. 
Garden - with sums that were attractive and meaningful in the sphere occupied by the 'proletarians', but which in the sphere that contained the transactions carried out by Orton were of no great economic significance. ${ }^{35}$

What was significant, however, was that Orton found himself in a predicament. He held the rapidly expiring bank notes of persons declared bankrupt, whereas his main creditor and - we may assume business partner, Captain Thomas Bishop had just returned from a sea voyage and expected payment. Orton insisted that he had taken steps to avoid bankruptcy, and knew very well that it would mean not only public disgrace - lists of bankrupts were published daily by the London press - but also relegation from the stratum of respectable businessmen. ${ }^{36}$ 'I beg leave to observe - he wrote from gaol - that if I had the least intentions of defrauding the Bank or Captain Bishop, should have gone abroad as soon as I heard of his arrival in Portsmouth [...] I had frequent opportunities of leaving my country but had not the least thought of the dreadful consequences'. Unable to pay his creditor, he feared financial ruin as he was indebted for the substantial sum for a minor businessman - of two thousand pounds. In desperation about which he wrote rather vaguely - he forged powers of attorney of Captain Bishop, who had entrusted him with the purchase and sale of his shares and the investment of monetary surpluses acquired during service at sea. By illegally acquiring Bank of England shares, worth five hundred pounds (other sources speak of a sum twice as great), Orton could - perhaps - avert the spectre of bankruptcy, but the unexpected return of the captain had accelerated the sequence of events. Can the forger be believed, when he informed his readers, that he immediately made several attempts to talk to his partner, probably in order to explain the situation and repaying (as he profoundly believed) his substantial liabilities? As he told his London readers, while waiting for another meeting he was arrested.

The frame of Orton's tale is not the problem of guilt or penance, although he seemed to accept the death sentence with a certain resignation, which could signify the influence of conversations with the cler-

${ }^{35}$ London Magazine, 20, 1751, pp. 43, 235. The world of London beggars is analysed by Tim Hitchcock, 'Begging on the Streets of Eighteenth-Century London', Journal of British Studies, 44, 2005, 3, pp. 478-98. Cf. Pieter Spierenburg, 'Close to the Edge: Criminals and Marginals in Dutch Cities', Eighteenth-Century Studies, 31, 1998, 3, pp. 355-59.

${ }^{36}$ Sheila Marriner, 'English Bankruptcy Records and Statistics before 1850', Economic History Review, New Series, 33, 1980, 3, pp.351-66, draws attention to complex procedures and the difficulties in estimating the number of persons declared bankrupt. 
gyman and reconciliation with God. ${ }^{37}$ His story is, above all, about the betrayal of trust. Several times Orton emphasized that he had parted with his main creditor, Captain Bishop, 'like a friend' but the fact that it was Bishop who had prompted the tip-off which had resulted in his arrest was a bitter surprise to Orton. As Laurence Fontaine has shown, early modern financial relations, which were based above all on the long-term value of credit and the omnipresent circulation of bankers' drafts, relied on mutual trust among businessmen. Moreover, although the French 'à credit' initially signified - still at the end of the seventeenth century - emotional and aimless deeds, the evolution of the concept and its transformation into the English 'credibility' shows not only the direction of the semantic journey, but also the underlying process of valuing relations, in which even people who did not know each other personally were ready to honour their signature and on that basis guarantee money. On the other hand, the explosion of the market economy and the credit possibilities of 'mercantile capitalism', which were already evident at the beginning of the eighteenth century, facilitated the abuse of trust, gave an incentive to speculation with the available means (bonds, shares and private banker's drafts), created a mirage of wealth and generated hitherto unknown temptations. ${ }^{38}$ If Pieter Spierenburg has told the Amsterdam stories of 'fatal attraction', adorned with the darker aspects of eighteenth-century love, then Orton's case provides proof of another emotion at work, for the effectiveness of the trap of naivety, into which a newly made businessman (a son of cheese mongers and a ship's clerk) could fall because he could not meet market requirements and financial obligations. To understand the social and cultural frames of the trap that snared Orton, Randall McGowen's conclusions are of fundamental importance. McGowen showed that the evolution of the crime of forgery, which was initially punished by fines and the 'shaming' sentence of the pillory was later treated significantly more harshly after the passing of the statute of 1729 . Forging a signature and embezzling money ceased to be a 'private' offence, because lawyers and royal judicial officials considered it to undermine the stability of the state, and threaten public order. It was understood that the effective functioning of the finan-

${ }^{37}$ The persistence of the interpretation of punishments handed down by courts in religious terms has been shown by J. A. Sharpe, 'Civility, Civilizing Process, and the End of Public Punishment in England', in Civil Histories. Essays Presented to Sir Keith Thomas, ed. Peter Burke, Brian Harrison and Paul Slack, Oxford, 2000, pp. $121 \mathrm{f}$.

${ }^{38}$ Laurence Fontaine, 'Antonio and Shylock: Credit and Trust in France, c. 1680 c. 1780', Economic History Review, New Series, 54, 2001, 1, pp. 39-57. On speculative 'bubbles' see Peter M. Garber, Famous First Bubbles: The Fundamentals of Early Manias, Cambridge, MA, 2000; Edward Chancellor, Devil Take the Hindmost: A History of Financial Speculation, New York, 1999. 
cial system depended on the exclusion of fraudsters from among those who transacted money. ${ }^{39}$

Did the case of Samuel Orton significantly change the rules of the London 'theatre of death'? The deed for which he was sentenced was not something unknown to the courts. Since 1729 forgery had been counted among the serious crimes against property and the penalties - mostly death sentences - appear ever more frequently in court judgments. On the one hand, this testifies to the dynamic growth of the public and private financial markets, and on the other it shows the system's vulnerability to abuse which was endemically short of cash and which depended on the circulation of its surrogates. The severity with which the courts treated forgers mirrored the conviction of the state judicial authorities and financial institutions that forging signatures was a serious threat to the modus operandi of the entire economic system. Announcements of the sentences passed on forgers regularly appeared in the newspapers. During the December 1743 session of the Old Bailey one out of the thirteen death sentences concerned the forging of a bank note; during the January session of 1751 two out of the thirteen death sentences were for forgery, and in the following session one out of nine. ${ }^{40}$

Orton's hanging was, therefore, nothing new, but the media gave him considerably more attention than other forgers. Cases involving financial instruments and real or imagined fraud were most often played out among London's 'middle class'. In his letter written from gaol Orton described his business trips to English ports; he traded in alcohol, but he was not a publican who serviced the criminal and 'proletarian' sub-culture of the street. He consciously shaped his profile as an entrepreneur. The description of his life and work that he offered to his readers defined - in his view at least - his 'class' and urban presence. In the eighteenth century we often find similar clashes between the image of a solid businessman and a catastrophe caused by an attempt to defraud the principles of his own ethos, for example the cases of the Perreau twins or Reverend Dodd. These cases caused surprise, provoked significant doubts as to the merits of the cases and the procedures followed, but they did not affect the severity of the judgments. Only after 1830 did such factors contribute to the change in the penal qualification of the crime. ${ }^{41}$ Samuel Orton sought to accentuate the

${ }^{39}$ Spierenburg, Written in Blood, (n. 3), pp. 13 ff.; Randall McGowen, 'From Pillory to Gallows: the Punishment of Forgery in the Age of the Financial Revolution', P\&P, 165, 1999, pp. 107-40.

${ }^{40}$ London Magazine, 12, 1743, p. 619; ibid., 20, 1751, pp. 43, 235.

${ }^{41}$ Craig Muldrew, The Economy of Obligation: The Culture of Credit and Social Relations in Early Modern England, London, 1998; Donna T. Andrew and Randall McGowen, The 
difference in his own case - and his social condition - and to underline his communal and individual 'self': in his correspondence from gaol, from the cell so cold that 'he could not even pray', he asked his readers in writing to forgive him his errors and with great determination sought permission from the municipal authorities to make his last journey in a closed coach. ${ }^{42}$ These were efforts through which he maintained to the end the image of his identity, defended his good name, and sought to avoid infamy. He was aware that he had left behind his wife and children, his circle of friends and his trading partners. His behaviour placed him in a social sphere in which the norm - still fluid - interacted with the idea of 'politeness': polished urban manners, correctness and ease in daily life and 'propriety' in professional activity. ${ }^{43}$ As Miles Ogborn has shown, the construction of the fabric of public life in the eighteenth century began increasingly to depend on the conscious presence of 'private individuals', different - and separated - from the amorphous, aggressive crowd of the street. $^{44}$

We can therefore speculate that Orton wished to die on his own terms. The cells in Newgate had a notorious reputation and prisoners occasionally died before the sentence could be carried out (which did not void the obligation to hang their bodies), while at Tyburn a hearse was waiting ${ }^{45}$ in order to take the body to the cemetery. He thus avoided the

Perreaus and Mrs. Rudd: Forgery and Betrayal in Eighteenth-Century, London and Berkeley, CA, 2001.

${ }^{42}$ London Magazine, 36, 1767, p. 38. Several days before his execution, Orton had demanded that he be moved to a different cell.

${ }^{43}$ This discussion is of vital importance for the description of English identity in the eighteenth century. Useful introductions are offered by: Henry French, 'The Search for the "Middle Sort of People" in England, 1600-1800', HJ, 43, 2000, 1, pp. 277-93; Paul Langford, 'The Uses of Eighteenth-Century Politeness', Transactions of the Royal Historical Society, 6th Series, 12, 2002, pp. 311-31; Lawrence E. Klein, 'Politeness and the Interpretation of the British Eighteenth Century', HJ, 45, 2002, 4, pp. 869-98; Karen Harvey, 'The History of Masculinity, circa 1650-1800', Journal of British Studies, 44, 2005, 2, pp. 296-311.

${ }^{44}$ Miles Ogborn, Spaces of Modernity: London's Geographies, 1680-1780, New York and London, 1998, pp. 79 f. Cf. Shoemaker, 'The Decline of Public Insult' (n. 8).

${ }^{45}$ The gaol used the remains of the medieval gate of entry to the City of London on its western side. It was considered to be exceptionally unhealthy. A typhus epidemic in 1750 spread to the neighbouring court buildings, killing several judges and jurors. Rebuilding of the gaol (comprising three wings - for debtors, women and men) commenced in 1770, but the new premises were burnt down in the Gordon Riots of 1780. See Harold D. Kalman, 'Newgate Prison', Architectural History, 12, 1969, pp.50-61. On the subject of the evolution of the undertaker's profession (from guild regulation to market competition) see Paul S. Fritz, 'The Undertaking Trade in England: Its Origins and Early Development, 1660-1830', Eighteenth-Century Studies, 28, 1994-1995, 2, pp. 241-53. 
fate of one of the companions of his last journey, Walker, condemned for highway robbery, whose colleagues (sailors) kidnapped the body from under the gallows, so that the corpse would not be handed over to surgeons for dissection and anatomical research, which in London street opinion was considered a final and shameful degradation. These efforts did not go unnoticed. It was written that 'Mr. Orton was the first criminal (except lord Ferrers) that has gone to Tyburn in a coach'. The comparison with the aristocrat who had been sentenced and hanged several years earlier for committing murder (he was the last member of the House of Lords to be hanged, the execution took place on 5 May 1760) should not be treated as a particular distinction for the legal qualification of the crime of forgery, as that was already unambiguous in 1767. Rather it is possible to discern the reflection of the changes in social qualifications and the individual properties of the convict's style - strongly shaped by the company he aspired to keep. Samuel Orton, a minor wholesaler of alcohol, managed to negotiate this special treatment from the managers of London's 'theatre of death'. ${ }^{46}$

(Translated by Richard Butterwick-Pawlikowski)

\section{Summary}

On January 14, 1767 Samuel Orton, London entrepreneur was driven to be hanged by a mourning coach. Most convicts, including those who travelled with him to the traditional city gallows at Tyburn were carted and the magistrates, who granted him this privilege were clearly making an exception. Orton's case

${ }^{46}$ For a case of hanging a chained corpse see the London Magazine, 6, 1737, p. 163. The condemned man was Jeffrey Morat, an Afro-Caribbean, who was found guilty of breaking and entering with intent to commit murder. Much significance was attached to the treatment of the body after execution. It was explained, for example, that the four Jews that were executed, were interr'd in their Burial-Ground at Mile-End, with their Cloaths on, and the Halters about their Necks, the Jews never stripping any Person, who does not die a natural Death', ibid., 13,1744, p. 100. Lord Ferrers killed his servant; after the execution his body was given to surgeons. See Langbein, 'Albion's Fatal Flaws', p. 114. In 1541 the guild of surgeons obtained the right to dissect the bodies of four convicts annually. The Murder Act of 1752 strengthened that right, which was considered an additional instrument of fear and infamy. See Peter Linebaugh, 'The Tyburn Riot Against the Surgeons', in Albion's Fatal Tree, pp. 65-117. The nineteenth century saw the flourishing of a criminal underground which procured bodies for surgeons. Cf. Ian Ross and Carol Urquhart Ross, 'Body Snatching in Nineteenth Century Britain: From Exhumation to Murder', British Journal of Law and Society, 6, 1979, 1, pp. 108-18. It seems, however, that these practices had eighteenth-century origins. Cf. 'On Saturday last a man was committed to New Prison, Clarkenwell charged with stealing diverse bodies from the burrying ground in Whitecross-Street, belonging to the parish of Cripplegate, and selling them to surgeons for two guineas each, on searching the ground empty coffins were found', Universal Magazine, 36, 1765, p. 275. 
and its analysis is informed by the detailed press reports read against the growing research into the evolution of London's eighteenth-century bloody code and urban 'theatres of death'. Strategies of penalizing crime are seen not as much in the light of statistics of death sentences as through their perception drawn by literate urban audiences from detailed press reports. The scenarios of hanging pirates, highwaymen and petty criminals traditionally included the edifying reports of the 'last dying speeches', while Orton, an educated businessman sentenced to death for a 'new crime' of forgery (punishable by death only from 1729) chose not to speak at the gallows but instead published an open letter professing himself a victim of market economy based on credit he could not satisfy. A death sentence mitigated by a gesture of granting him a coach is thus - on the one hand - a mark of lawmakers' growing determination to penalize financial transgression, while - on the other - a sign of lingering social and ethical ambiguity about harshness such decisions of the court.

Pawet Dobrowolski 